insolation. Spethmann stated that in the Alps transport by wind was certainly not often the primary cause ; there the transport of sand by water was a more important factor.

I agree with these opinions, and here I would merely mention two observations which I once made. In 192 I I saw that on the flat part of the Upper Grindelwald Glacier the stream of water from the snow and ice in its meanders melted a circular flat depression in the ice as shown in the drawing on p. 367 . While the water kept flowing through and passing round in spiral eddies, a thick layer of sand remained lying in the quiet centre of the depression. Downhill, a transverse crevasse cut across the glacier. I then considered that the following would happen: the glacier is moving downhill, and as soon as this meander belt has reached the crevassed region the stream will fall into the newly formed crevasse, while the depression caused by the meander will remain dry and with the sand in it. Then, in time, just as the leg of a glacier table is produced under a block of rock by insolation, here an ice-cone will be formed, over which the sand will lie like a cape over a man's shoulders.

I would also like to state that I once observed how dirt cones are produced from another cause: until about I920, the north-east end of the Clariden Firn (Canton Glarus, Switzerland) still lay below the rocks near its end on which the hut of the Swiss Alpine Club stands. In the following years the general shrinkage of the glacier began. The upper surface sank down, becoming quite concave. The slope between the rocks above and the glacier below became continually wider. It consisted of ground moraine and marly weathered rubble. One day the rubble slid down at a certain place over a front of about $20 \mathrm{~m}$. and settled on the flat part of the glacier, thereby forming low, wreath-shaped humps, such as are typical in cases of solifluction. To my astonishment, in the following autumn I found a group of several black sand cones there, some of them I $\mathrm{m}$. high. Investigation showed that there was old glacier ice under the covering of sand. In the following year, only three of these cones still remained. Neither in the previous years, nor in subsequent years right up to the present day, have cones of any considerable size been observed, so that the cause of the single occurrence of those sand cones was the mud covering of the small solifluction.

\title{
CORRESPONDENCE
}

The Editor, The Fournal of Glaciology

Sir,

\section{Alpine Glaciers}

Will you kindly afford space in the fournal for a reply to some of the criticisms put forward by Mr. Side in his review of my book Alpine Glaciers in Vol. 2, No. 12, of the fournal? He incorrectly suggests that $I$ have erred in stating the total length of the Great Aletsch Glacier as being 15 miles, owing to my having overlooked the fact that the upper reaches consist of the Jungfraufirn and the Grosser Aletschfirn. As a matter of fact my statement was really intended to indicate the approximate length of the whole glacier system from snout to bergschrund, the upper portions, the firn, being treated and named as part of the glacier as a whole, as is frequently the procedure in the case of a river, the original rill at the source of which bears the name of the larger stream into which it eventually develops. The portion known as the Great Aletsch Glacier proper, commencing at the Lötschenlücke, is certainly not more than about $13 \frac{1}{2}$ miles in length, but the inclusion of the Jungfraufirn, or of the even longer tributary the Ewigschneefeld, would bring the total length up to the 15 miles stated.

As to statements which might be misleading to mountaineers, the book contains only such information as I have gathered from my own experience, and my guides have always been of high repute.

In his concluding paragraph Mr. Side generously acknowledges that the book accomplishes the purpose for which it was intended. It is a pity that it should receive adverse criticism on account of my having used a term in its widest application, or on points which are really controversial.

66 Shanklin Drive,

A. E. Lockington Vial

Leicester

24 October 1953 